\title{
IL10RB wt Allele
}

National Cancer Institute

\section{Source}

National Cancer Institute. IL10RB wt Allele. NCI Thesaurus. Code C51356.

Human IL10RB wild-type allele is located in the vicinity of $21 \mathrm{q} 22.11$ and is approximately $31 \mathrm{~kb}$ in length. This allele, which encodes interleukin-10 receptor subunit beta protein, is involved in signal transduction and interleukin-10 regulation. 